\title{
Dynamics of morphological and anatomical changes in leaf tissues of an interspecific hybrid of oil palm during acquisition and development of somatic embryogenesis
}

\author{
Hugo Teixeira Gomes ${ }^{1}$ Patrícia Monah Cunha Bartos ${ }^{1}$. \\ Jonny Everson Scherwinski-Pereira ${ }^{2}$ (i)
}

Received: 6 March 2017 / Accepted: 16 July 2017 / Published online: 29 July 2017

(C) Springer Science+Business Media B.V. 2017

\begin{abstract}
Oil palm is an economically important plant species due to its high oil production per unit area. Largescale clonal propagation of the species's elite specimens is only possible through somatic embryogenesis, although methodology is partially still unknown and insufficiently understood. Current study characterizes in morphological and anatomical terms the acquisition and development stages of somatic embryogenesis of the oil palm's immature leaves. The respective embryogenic stages were analyzed and characterized: immature leaves (initial explants); leaves with calli formation; leaves which failed to respond to calli formation; leaves with formation of root structures; primary calli; primary calli with differentiation of embryogenic calli; embryogenic calli; pro-embryogenic calli; calli with differentiated somatic embryos; somatic embryos at globular and torpedo stage; and mature fruit zygotic embryos. Cell masses emerged after approximately 60 days of cultivation through the proliferation of cells associated to initial explants' vascular bundles. Consequently, the formation of two different types of calli was identified, namely, primary and embryogenic, respectively consisting partially and completely of meristematic cell clusters. After
\end{abstract}

Communicated by Konstantin V. Kiselev.

Electronic supplementary material The online version of this article (doi:10.1007/s11240-017-1282-8) contains supplementary material, which is available to authorized users.

Jonny Everson Scherwinski-Pereira

jonny.pereira@embrapa.br

1 Institute of Biology, University of Brasília, PPGBOT, Brasília, DF 70910-900, Brazil

2 Embrapa Genetic Resources \& Biotechnology, Av. W5 Norte (Final), PqEB, Brasília, DF 70770-917, Brazil
420 days of cultivation, the propagules formed somatic embryos with no connection to source tissues, initially composed (globular stage) of a very characteristic ground meristem and protoderm. After 480 days of cultivation, as the cultures matured (torpedo stage), procambial strands, a structural characteristic also observed in mature zygotic embryos, were reported. The results provide an in-depth understanding of somatic embryogenesis of immature leaves of oil palm. Further, current analysis develops morphological markers at different stages of development obtained during the process.

Keywords Arecaceae Elaeis spp. Morphogenesis · Ontogenesis $\cdot$ Somatic embryos $\cdot$ Woody plants

\section{Introduction}

The oil palm is economically relevant in the world scenario due to its high production of vegetable oil per unit area, with yields up to 8 tons per hectare year ${ }^{-1}$ (Hoffmann et al. 2014). However, in the wake of its allogamous culture exclusively propagated by seeds, an important impairment in oil palm farming is the formation of heterogeneous crops which cause lack of uniformity in production and limitations in the distribution of superior genotypes, coupled to difficulties in the performance of crop management practices (Wahid et al. 2005).

The possibility of producing genetically identical plants from phenotyped elite specimens in the field would significantly increase the crop's profitability. Nonetheless, due to the morphological, anatomical and physiological nature of oil palm, large-scale clonal propagation is only possible through somatic embryogenesis (Jouannic et al. 2011; Soh et al. 2011). Somatic embryogenesis is the method whereby 
haploid or somatic cells develop from an ordered series of characteristic embryogenic stages, but without the fusion of gametes (Reinert 1958; Williams and Maheswaran 1986). Bipolar structures are consequently formed with no vascular connection with parental tissues, closely resembling zygotic embryos (Luis and Scherwinski-Pereira 2014; Leljak-Levanić et al. 2015).

Several protocols for somatic embryogenesis have been developed for oil palm owing to advantages in employing superior clones (Staritsky 1970; Corley et al. 1977; Duval et al. 1988; De Touchet et al. 1991; Teixeira et al. 1994; Rival et al. 1997; Choi et al. 2008; Scherwinski-Pereira et al. 2010; Constantin et al. 2015; Jayanthi et al. 2015; Wiendi et al. 2015; Lim et al. 2016). However, the species's somatic embryogenesis is insufficiently known and understood. To date, protocols developed for the crop still provide several limitations, such as the formation of calli with low morphogenic potential, lack of synchronization in embryogenic development, low conversion rate of somatic embryos and regeneration of incomplete plants (Konan et al. 2010; Soh et al. 2011; Silva et al. 2012; Thuzar et al. 2012; Gomes et al. 2015, 2016).

Moreover, the occurrence of certain morphological and anatomical anomalies in the somatic embryogenesis of the oil palm, such as the fusion of embryos, underdevelopment of apical meristems and loss of propagules' bipolarity, has also made it difficult to establish effective methods for clonal propagation of the species's elite specimens (Habib et al. 2012). Consequently, the morphological and anatomical monitoring of somatic embryogenesis of oil palm becomes crucial to better understand the process, select treatments that best minimize the occurrence of anomalies and, consequently, enhance the protocols developed (Angelo et al. 2013; Silva et al. 2014).

Current analysis investigates and characterizes morphologically and anatomically the acquisition and development stages of somatic embryogenesis of immature leaves of an interspecific hybrid of the oil palm.

\section{Materials and methods}

\section{Plant material}

Immature and still unexpanded leaves of an interspecific F1 hybrid of Elaeis oleifera $\times$ E. guineensis, derived from cross between E. oleifera (Manicoré) and E. guineensis (La Mé), were used as plant material to induce somatic embryogenesis. The material, called variety B35-1733, was provided by the Oil Palm Genetic Improvement Program of Embrapa Western Amazonia in the municipality of Rio Preto da Eva, Amazonas, Brazil.

\section{Explants}

After collection, the plant material was taken to the laboratory. The outermost leaves were removed and the length of the palm hearts reduced to approximately $30 \mathrm{~cm}$ (from proximal to the distal region of the meristem). Immature non-chlorophyllated leaves, obtained from the central cylinder of the collected palm hearts, were disinfected by washing in a solution of water and commercial detergent, followed by immersion in $70 \%$ alcohol for $3 \mathrm{~min}$ and immersion in sodium hypochlorite $(\mathrm{NaOCl}) 2.5 \%$ active chlorine for $20 \mathrm{~min}$.

Explants were obtained when sterile leaf segments, measuring approximately $1 \mathrm{~cm}^{2}$, were inoculated on Petri plates $(15 \times 90 \mathrm{~mm})$, with the adaxial side facing down, by $25 \mathrm{~mL}$ of culture medium composed of a saline solution and MS vitamins (Murashige and Skoog 1962), supplemented with $450 \mu \mathrm{M}$ of picloram (4-amino 3, 5, 6-trichloropicolinic acid) (Sigma, St. Louis, MO, USA), $0.5 \mathrm{~g} \mathrm{~L}^{-1}$ hydrolyzed casein, $0.5 \mathrm{~g} \mathrm{~L}^{-1}$ glutamine, $2.5 \mathrm{~g} \mathrm{~L}^{-1}$ activated charcoal, and $30 \mathrm{~g} \mathrm{~L}^{-1}$ sucrose (Balzon et al. 2013). The medium's $\mathrm{pH}$ was adjusted to $5.7 \pm 0.1$ and $2.5 \mathrm{~g} \mathrm{~L}^{-1}$ of Phytagel (Sigma, St. Louis, MO) were added prior to sterilizing at $121^{\circ} \mathrm{C}$, at $1.3 \mathrm{~atm}$, during $20 \mathrm{~min}$. Plant material was then cultivated up to eight 30-day subcultures to obtain calli, in the dark, to reduce the explants' phenolic oxidation rates (Alkhateeb 2008).

The calli obtained during the induction phase were inoculated in $250-\mathrm{mL}$ glass bottles with $40 \mathrm{~mL}$ of MS nutrient medium supplemented with $12.3 \mu \mathrm{M}$ of 2 -iP (isopentenyl adenine) and $0.54 \mu \mathrm{M}$ NAA (1-naphthalene acetic acid), $0.5 \mathrm{~g} \mathrm{~L}^{-1}$ glutamine, $0.5 \mathrm{~g} \mathrm{~L}^{-1}$ hydrolyzed casein, $30 \mathrm{~g} \mathrm{~L}^{-1}$ sucrose, $2.5 \mathrm{~g} \mathrm{~L}^{-1}$ Phytagel, adjusted to $\mathrm{pH} 5.7 \pm 0.1$. At this stage, the calli were cultivated for six 30-day subcultures to interrupt repetitive cycles of cell division and provide stimuli for somatic embryos differentiation.

The somatic embryos from the differentiation stage were then inoculated in 1 L-recipients for automated temporary immersion (R.I.T.A. ${ }^{\circledR}$ ), containing $200 \mathrm{~mL}$ of liquid culture medium (Gomes et al. 2016). Medium comprised MS vitamins and salts devoid of growth regulators, supplemented with $30 \mathrm{~g} \mathrm{~L}^{-1}$ sucrose and $2.5 \mathrm{~g} \mathrm{~L}^{-1}$ activated charcoal, adjusted to $\mathrm{pH} 5.7 \pm 0.1$. The somatic embryos were then cultivated up to two 30-day subcultures to complete the maturation process and start germination.

During the whole embryogenic development, the cultures were placed in a growth chamber at $25 \pm 2{ }^{\circ} \mathrm{C}$, during a 16-h photoperiod, and LED-light radiation of $52 \mu \mathrm{mol} \mathrm{m}{ }^{-2} \mathrm{~s}^{-1}$ (Philips ${ }^{\circledR}$ Green Power $20 \mathrm{~W} 60 \mathrm{~Hz}$ ). 


\section{Anatomical analysis}

So that the stages of acquisition and development of somatic embryogenesis of oil palm by leaf explants could be morphologically and anatomically characterized, immature leaves (initial explants), leaves with callus formation, leaves that did not respond to callus formation, leaves with formation of root structures, primary calli, primary calli with differentiation of embryogenic calli, embryogenic calli, pro-embryogenic calli, calli containing differentiated somatic embryos, and somatic embryos at the globular and torpedo stage were analyzed, following Silva et al. (2014). Mature fruit zygotic embryos were also assessed in current study to compare their profile with that of the somatic embryos obtained.

Five samples of each developmental stage were initially viewed and analyzed under a stereomicroscope with image capture system (Leica ${ }^{\circledR}$ EZ4 HD), whereby their shape, appearance, consistency and color were evaluated. Samples were inoculated in 2-mL wells and subjected to fixation in FAA 50\% (formaldehyde 37-40\%, glacial acetic acid and ethanol 50\% 1:1:18, v/v) for $48 \mathrm{~h}$. After fixation, the samples were dehydrated in increasing alcohol series (50-100\%) and then infiltrated and included in historesin $\left(\right.$ Leica ${ }^{\circledR}$ ). Transverse and longitudinal serial sections up to $10 \mu \mathrm{m}$ thick were subsequently obtained on a manual rotary microtome (Leica, RM2125RT). The sections obtained were stretched and adhered to microscope slides with a plate heated up to $40^{\circ} \mathrm{C}$. The anatomical sections were then stained with toluidine blue (O'brien et al. 1965), mounted with Entellan (Merck, Darmstadt, Germany) and then viewed and analyzed under an optical light microscope locked to an image capture system (Leica ${ }^{\circledR}$ DM750).

\section{Results and discussion}

Leaf segments, measuring approximately $1 \mathrm{~cm}^{2}$, were used as initial explants in the somatic embryogenesis of immature oil palm leaves. Explants were morphologically characterized as having smooth surface, pliable texture, lacking chlorophyll and parallel ribbing (Fig. 1a). Histological analysis showed that leaf segments have a prominent midrib on both sides, consisting of a vascular system comprising a large central cylinder associated with four or five isolated vascular traces, facing the adaxial surface and contoured by a layer of sclerenchymatous cells (Fig. 1b).

The anatomical sections of the immature leaves of oil palm plants used as initial explants for somatic embryogenesis revealed that the mesophyll is dorsiventral. Two or three layers of palisade parenchyma were observed in this region of the leaf. They were composed of elongated bar-shaped cells arranged in rows and located immediately beneath the adaxial hypodermis. There were also
Fig. 1 Morphological and anatomical aspects of leaf segments used as initial explants in the somatic embryogenesis. a External morphology; b-d anatomical sections. Arrows indicate vascular bundles. $a b$ abaxial side, $a d$ adaxial side, $h p$ hypodermis, $I m$ leaf mesophyll, ph phloem, sc substomatal cavity, ep epidermis, sto stomata, $v b$ vascular bundle, $p p$ palisade parenchyma, $s p$ spongy parenchyma, st sclerenchyma tissue, $x$ xylem. Bars $\mathbf{a}=2 \mathrm{~mm} ; \mathbf{b}$, $\mathbf{c}=0.2 \mathrm{~mm} ; \mathbf{d}=0.05 \mathrm{~mm}$
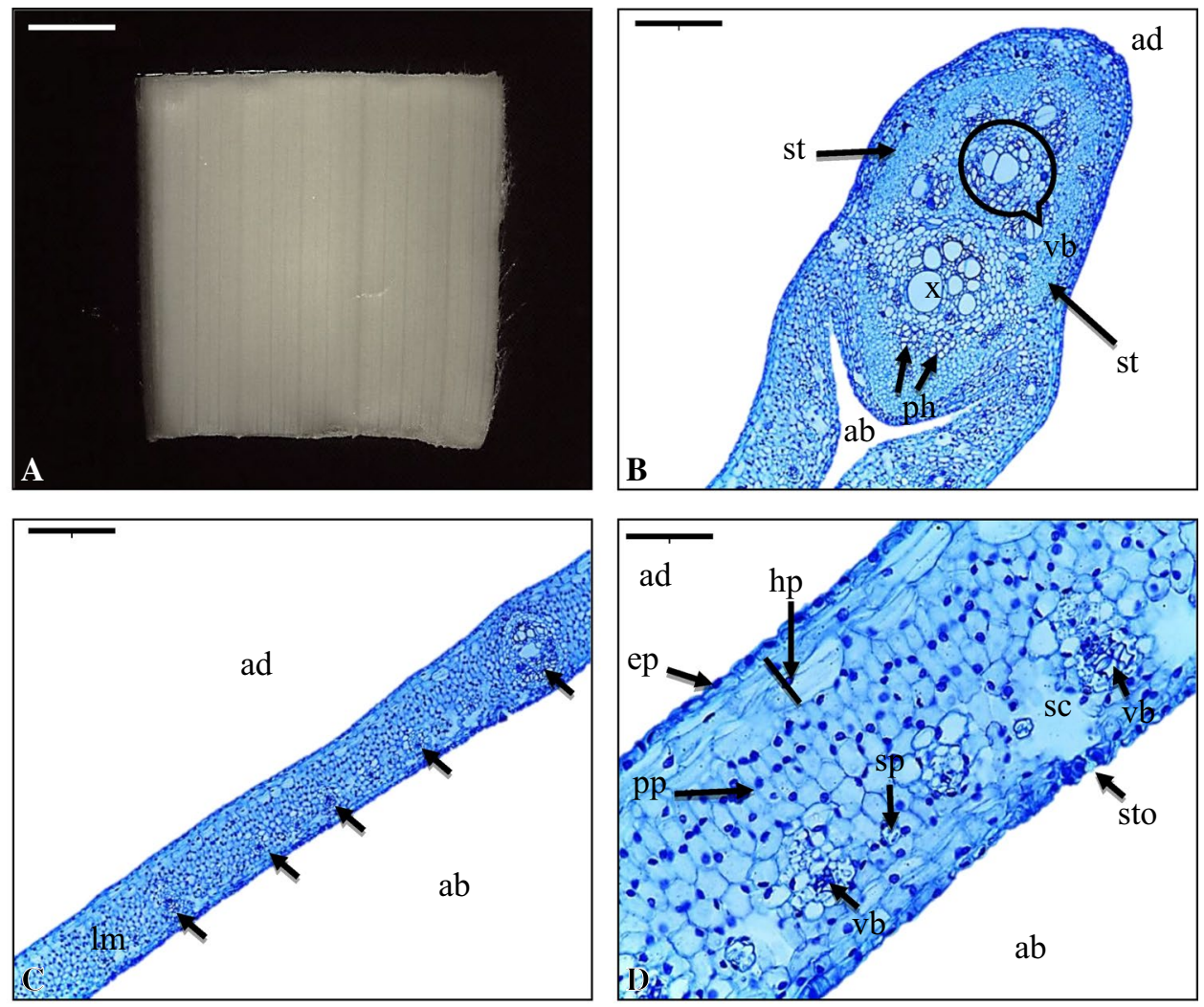
two or three layers of spongy parenchyma in the same region, composed of more rounded cells with small intercellular spaces. Undeveloped vascular bundles dispersed throughout the leaves' mesophyll have also been observed (Fig. 1c). Further, explants exhibited a uniseriate epidermis consisting of rectangular-shaped cells, juxtaposed, strongly bound together, revealing stomata with large substomatal cavity on the abaxial surface only (hypostomatic leaf). Furthermore, below the epidermal layer, on both sides of the leaf, there was a bi-layered hypodermis consisting of cells that were larger than the epidermal ones (Fig. 1d). Results corroborated those by Luis et al. (2010) who, when analyzing the anatomical characteristics of oil palm leaves, also reported a midrib made up of a larger vascular bundle associated to smaller vascular bundles, stomata located only in the epidermis of the abaxial side of the leaf, hypodermis on both leaf surfaces and other characteristics.

The leaf segments used as initial explants were then cultured for 240 days in MS medium, supplemented with $450 \mu \mathrm{M}$ picloram, to induce the oil palm's somatic embryogenesis. At this stage (60 days of cultivation), callus formation started in some of the explants, morphologically characterized by the rupture of some regions of the epidermis coupled to the emergence of compact brownish-beige agglomerates, featuring a slightly rounded shape and watery consistency (Fig. 2a). Histological observations made at the beginning of the induction phase of somatic embryogenesis of oil palm showed that callus development was associated with vascular bundle in all propagules analyzed, which occurred mainly in the regions close to the edge of the excised explants, with greater contact between the vascular tissues and the components of the nutrient medium.

At this phase of somatic embryogenesis, cell divisions that gave rise to the calli started close to well-developed vascular bundles, where the presence of smaller-sized cells, with dense cytoplasm and a clearly visible nucleus, were reported. Cell proliferation in this process was carried out initially by periclinal division, resulting in the development of rowed cells and increased leaf thickness (Fig. 2b-d). As
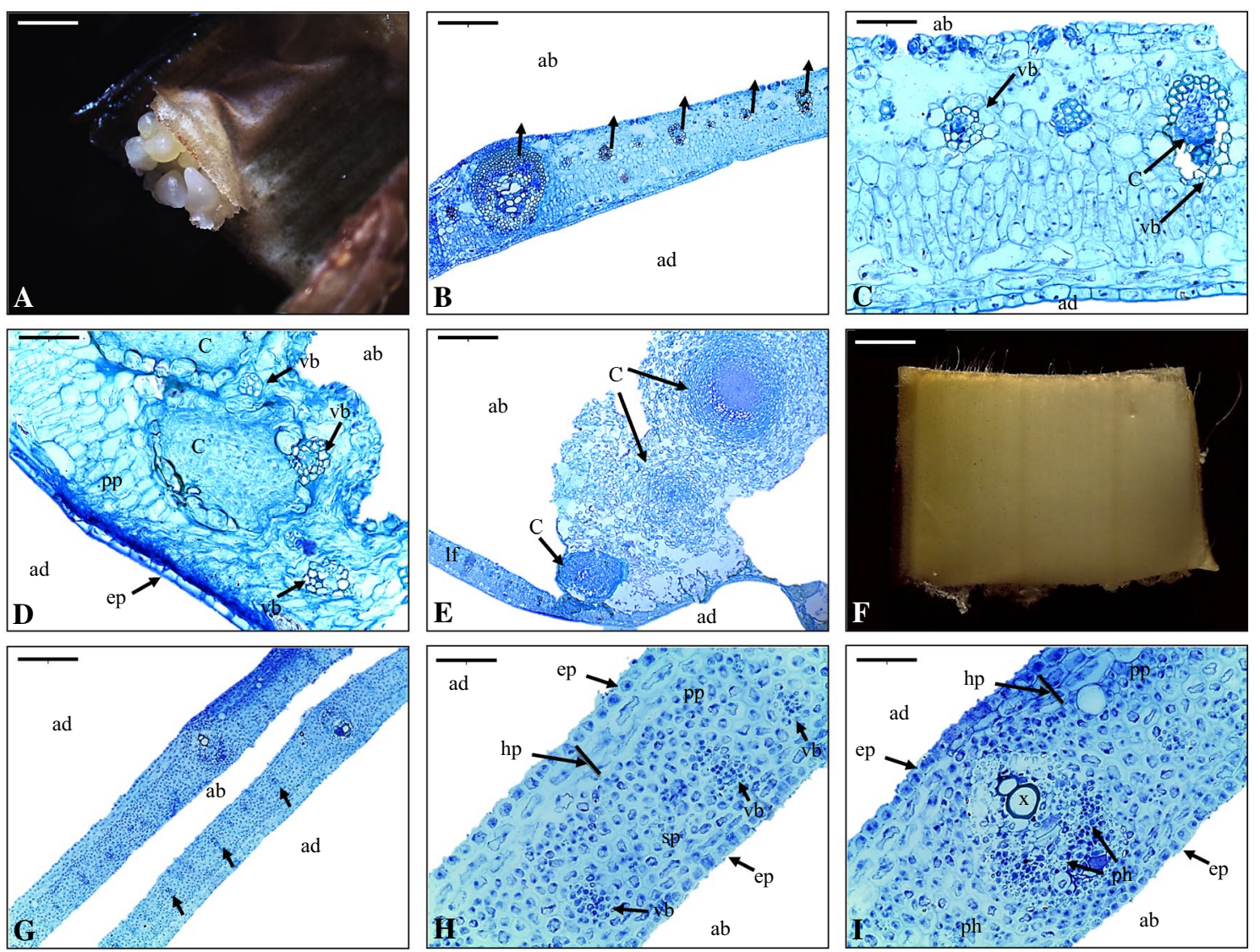

Fig. 2 Morphological and anatomical aspects of leaf segments with early callus formation after 60 days in callus induction medium (a-e) and leaf segments that do not respond to the callus induction after 240 days in callus induction medium $(\mathbf{f}-\mathbf{i})$. Arrows indicate welldeveloped vascular bundles (b) and underdeveloped vascular bundles (g). $a b$ abaxial side, $a d$ adaxial side, $C$ callus, $e p$ epidermis, $v b$ vascular bundle, If leaf, $s p$ spongy parenchyma, $p p$ palisade parenchyma, $p h$ phloem, $h p$ hypodermis, $x$ xylem. Bars $\mathbf{a}, \mathbf{f}=2 \mathrm{~mm} ; \mathbf{b}, \mathbf{g}=0.2 \mathrm{~mm}$; $\mathbf{c}-\mathbf{i}=0.05 \mathrm{~mm} ; \mathbf{e}=0.5 \mathrm{~mm}$ 
the calli developed, the palisade parenchyma cells adjacent to these cell masses showed a slight flattening due to compression against the epidermal cells of the adaxial surface, increasing in width and decreasing in height. However, the spongy parenchyma cells and the epidermal cells of the abaxial face, contiguous to the callus, ruptured as the propagules developed (Fig. 2e).

In the somatic embryogenesis of oil palm from leaf explants, Schwendiman et al. (1988) determined that procambium cells produce cell masses. Whereas, according to Duval et al. (1995), in the somatic embryogenesis of immature leaves of E. guineensis, callus formation starts with the multiplication of perivascular cells near the xylem, resulting in a layer of meristem tissue, four to five cells thick. Jones (1983) reports that in the somatic embryogenesis of oil palm, the multiplication of perivascular cells formed centers with high meristem activity, from which the calli originate. Callus formation from regions close to the vascular tissues of the explants has also been reported in several species of the Arecaceae family, such as Phoenix dactylifera (Sané et al. 2006), Acrocomia aculeata (Moura et al. 2009) and Bactris gasipaes (Steinmacher et al. 2011).

A significant number of explants that failed to react to the callus induction process $(77.7 \%)$ was also observed during the induction phase of somatic embryogenesis in oil palm from leaf explants. The immature leaves of oil palm that failed to originate any callus were morphologically characterized as having a smooth surface, a more rigid texture and a yellowish color when compared to the explants at the beginning of the culture (Fig. 2f). Unlike the leaf segments with callus formation, no stomata were identified in the epidermis of the abaxial side of the leaves in the anatomical sections of these explants. Propagules revealed that the mesophyll was also composed of homogeneous parenchyma, with 6-8 layers of isodiametric cells with few intercellular spaces in which relatively less developed vascular bundles were dispersed (Fig. 2g-i). These histological characteristics demonstrated that leaf segments that do not respond to callus induction were anatomically more immature than the leaf segments in which callus formation was observed.

However, contrary to what has been observed in current study, Scherwinski-Pereira et al. (2010), in their analysis of the somatic embryogenesis of E. guineensis via thin cell layer (TCL), reported that explants from the basal region of the plant generally had a significantly higher percentage of callus formation than that obtained in explants taken from the most apical positions of the palm heart, i.e., more highly developed explants. According to the above authors, these results may be due to the larger quantity of little-differentiated and/or non-differentiated (meristematic) tissues in the explants. Steinmacher et al. (2007) also concluded that, in somatic embryogenesis of peach palm via TCL, callus formation is significantly higher in explants from the more immature regions of the leaves. According to the authors, the above results may be due to the morphogenic competence of the explants which is mainly determined by the capacity of its cells to re-enter the mitotic cycle. Consequently, younger tissues have higher embryogenic potential.

However, leaf segments from the palm heart regions, between 15 and $30 \mathrm{~cm}$ of the meristem base, are greatly recommended for the induction of somatic embryogenesis from immature leaves of adult oil palm plants. The method not only reduces the probability of damaging the apical meristem of the matrix plant for later regrowth, but also and mainly increases efficiency at this stage of cultivation.

A single explant with root-like structures was exceptionally observed at this stage of cultivation (Electronic Supplementary material; Fig. S1A-D). These structures were morphologically characterized as being non-chlorophyllated cylindrical appendices with many root hairs and beige-brown coloration (Fig. S1A). Anatomically, a point of direct connection between the root and the leaf explant has been observed, characterizing a process of direct organogenesis. However, cellular clusters, similar to those of primary calli close to the root structure region, have also been identified. In addition, visible vascular tissues and the root's apical meristem region were also observed through the longitudinal sections of these roots, in which periclinal divisions that resulted in the formation of flattened and queued cells initially predominated. Further, the root tip region was clearly distinct from the other regions owing to smaller cells with darker coloration (Fig. S1b-c). Finally, an epidermal region was observed in the transversal sections of the formed roots. It had elongated and queued cells that circumvented the root's entire periphery. Internally to this layer, 4-9 layers of smaller, more round-shaped cells that make up its cortical region, were detected, whilst, more internally, a vascular region composed of meristematic cells was verified (Fig. S1d).

At the end of the somatic embryogenesis induction phase of the oil palm's immature leaves, however, significant levels of primary callus formation (22.3\%) were also achieved. Primary calli obtained during the cultivation period were morphologically characterized as having a primarily elongated shape, a compact appearance, a slightly watery consistency and a brown-beige coloration (Fig. 3a). Anatomical analyses showed that there were different cell regions in the propagules. In the callus's peripheral region, lining cells featured an elongated shape, large intercellular spaces and well-developed vacuoles. In the middle region, sectors with relatively large and vacuolated parenchymal cells were observed. Finally, the internal region of these formations was characterized by a meristem zone with small isodiameter cells with dense cytoplasm, narrower cell wall, and a high nucleus-cytoplasm ratio (Fig. 3b-d). 
Fig. 3 Morphological and anatomical aspects of primary calli after 240 days and primary calli with formation of embryogenic calli after 180 days in callus induction medium. a, e External morphology; b-h anatomical sections. $c p c$ callus's peripheral region, $p c$ parenchyma cells, $m z$ meristematic zone, $E C$ embryogenic callus, $P C$ primary callus. Bars $\mathbf{a}, \mathbf{e}=2 \mathrm{~mm} ; \mathbf{f}=0.5 \mathrm{~mm}$; $\mathbf{b}-\mathbf{g}=0.2 \mathrm{~mm} ; \mathbf{d}, \mathbf{h}=0.05 \mathrm{~mm}$
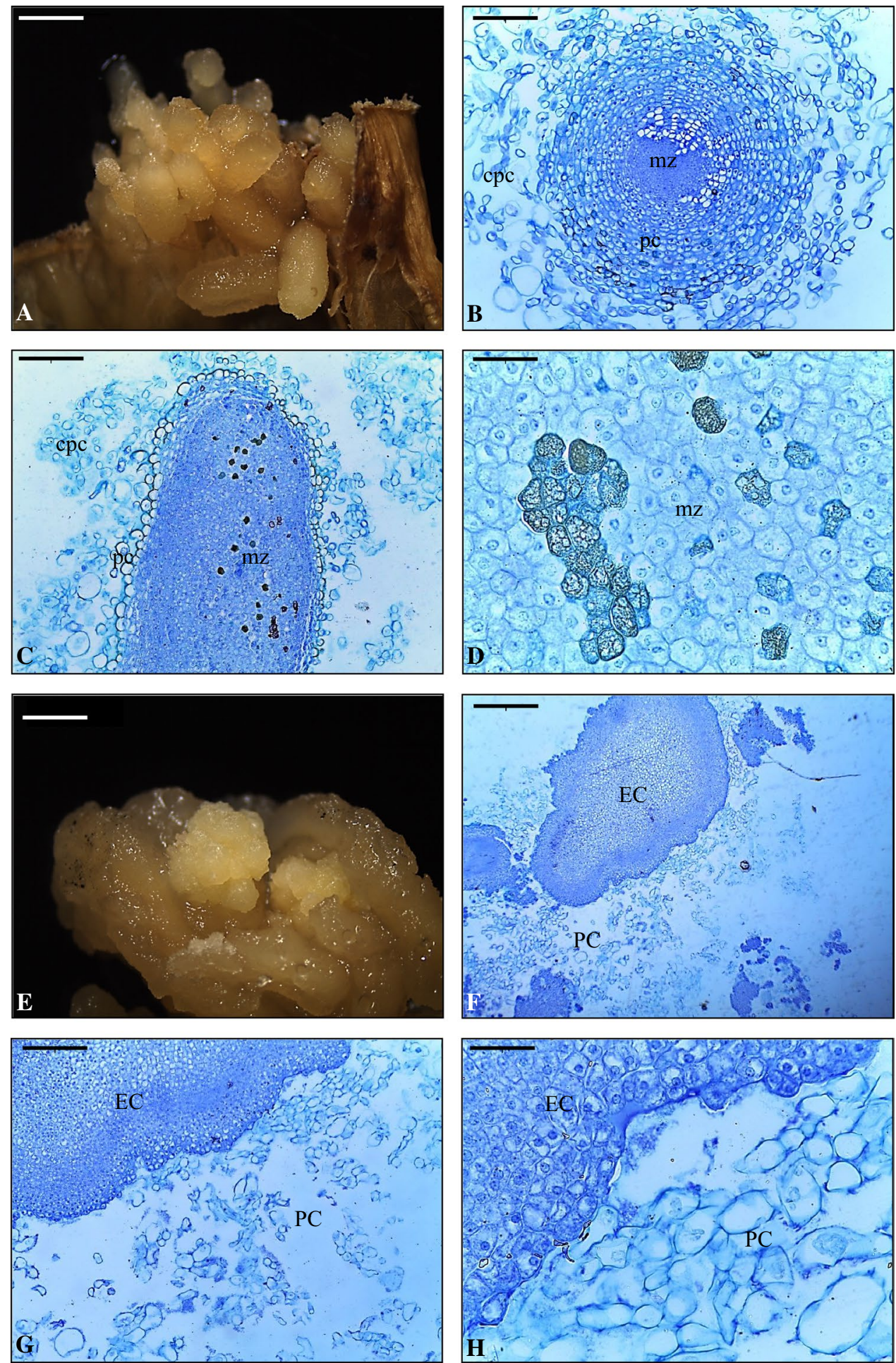

In the somatic embryogenesis of $E$. guineensis by mature fruit zygotic embryos, Balzon et al. (2013), based on histological sections, also demonstrated the proliferation of a meristem zone in the internal part of the primary callus. The region consists of small isodiametrically shaped cells, dense cytoplasm and large nuclei. Similar results were also reported by Thuzar et al. (2012), who, in recloning oil palm plants by somatic embryogenesis via TCL, also detected a meristem zone in the anatomical sections of primary calli, consisting of cells with highlighted nuclei, dense cytoplasm, parenchyma cells and callus lining cells.

In the peripheral region of primary calli, albeit at a low frequency (13.1\%), a sort of callus with different morphological characteristics than those in the primary 
callus was also observed. In the initial stage of development, cell masses were characterized by a yellowish coloration, a slightly less aqueous aspect, compact shape and reduced size (Fig. 3e). The anatomical sections revealed peripheral and vacuolated cells of the primary callus bypassing the basal region of the secondary callus which, in turn, was composed of a compact arrangement of tiny cells in intense cellular activity (Fig. $3 \mathrm{f}-\mathrm{h}$ ). However, this secondary callus may have originated from cells of the primary callus's meristem zone since they are more differentiated cells and more similar to those in the second callus type. Within the context of the somatic embryogenesis of the species, de Touchet et al. (1991) also reported the appearance of small colored nodules slightly attached to the remainder of the beige-colored callus, anatomically characterized as meristem aggregates, at the periphery of the parenchymal tissue of the primary callus. However, according to Duval et al. (1995), this type of callus is rarely evidenced in oil palms.

In their most advanced stage of development (at the end of the induction stage), the embryogenic calli were morphologically characterized as exhibiting a friable aspect, a less watery consistency and a yellowish coloration (Fig. 4a). The anatomical sections revealed that this type of callus, unlike the primary callus, is entirely made up of small isodiameter cells with dense cytoplasm, narrower cell walls and clearly visible nuclei, i.e., meristem cells. An histological analysis of the propagules also showed that some of the cells at their edge exhibit two nucleoli in the same nucleus, thus showing incomplete cytokinesis in the process of cell division (Fig. 4b-d).

In the histological study of somatic embryogenesis of $E$. guineensis, Schwendiman et al. (1988) showed that, similar to current study, embryogenic calli were basically composed of cells with meristematic characteristics, i.e., small isodiameter cells with dense cytoplasm, clearly visible nuclei and narrower cell walls.

During morphological and anatomical characterization of pro-embryogenic masses of oil palm plants, induced from somatic embryogenesis of leaf explants, Padua et al. (2013) reported the existence of different types of callus. In fact, the histological sections in calli with higher embryogenic potential also revealed that cell masses consisted mostly of small isodiametric cells, with dense cytoplasm, prominent nucleoli, small intercellular spacing and high nucleus-cytoplasm ratio, or rather, standard cell characteristics of meristematic clusters.

Besse et al. (1992) observed in the somatic embryogenesis of E. guineensis the formation of a characteristically compact, organized and nodular primary callus, and a typically embryogenic callus, characterized by friable aspect, whitish coloration and rapid growth. However, contrary to what has been reported in current study, the anatomical analysis of these propagules revealed small groups of meristem cells associated to a higher number of expanded and vacuolated cells. Moreover, the rapidly growing calli were directly involved in the formation of mantled specimens, since they maintained intensive multiplication for
Fig. 4 Morphological and anatomical aspects of embryogenic calli after 240 days in callus induction medium. a External morphology; b-d anatomical sections. Arrows indicate the process of cell division. $E C$ embryogenic callus. Bars $\mathbf{a}=2 \mathrm{~mm} ; \mathbf{b}=0.5 \mathrm{~mm} ; \mathbf{c}$, $\mathbf{d}=0.05 \mathrm{~mm}$
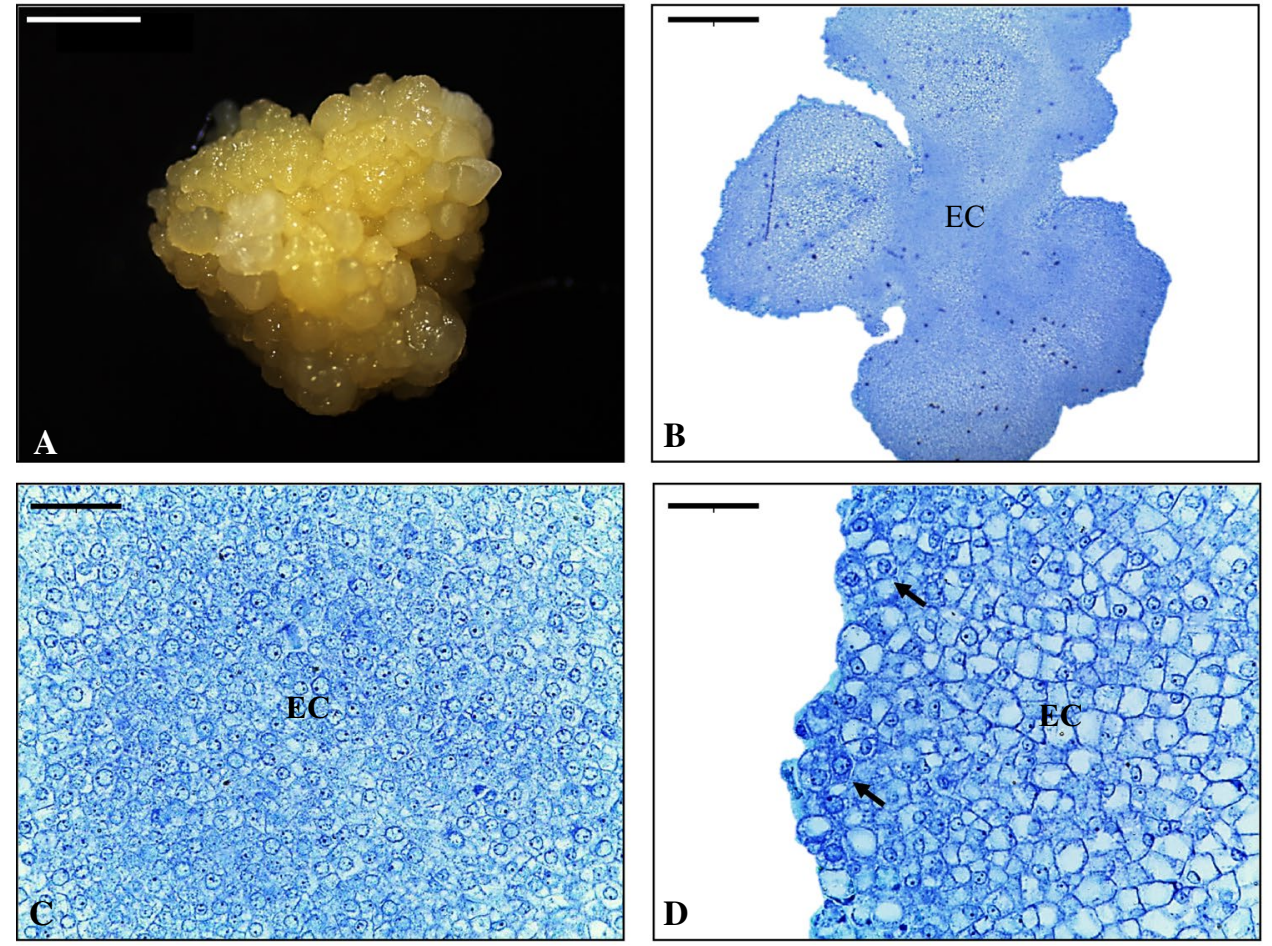
long periods. The authors suggested, as in current protocol, that calli should not be multiplied by many subcultures to prevent the occurrence of such anomalies.

After the induction phase of somatic embryogenesis of immature leaves of oil palm, the primary calli obtained were then cultured for up to 180 days in different media. At the end of this process, a small number of primary calli with formation of somatic embryos (approximately $5 \%$ ) was observed. The somatic embryos originating from the propagules were morphologically characterized by an opaque aspect, whitish coloration, slightly watery consistency and round shape (Fig. 5a). The anatomical sections in these cultures revealed differentiation of somatic embryos at an early stage of development (globular), consisting of meristem cells, disconnected to the source explant cells and completely bounded by a characteristic protoderm (Fig. 5b-d).

In their study on the origin and development of embryos of E. guineensis, obtained by somatic embryogenesis of zygotic embryos, Kanchanapoom and Domyoas (1999) observed that, based on the cultivation of primary calli in a differentiated medium, somatic embryos were formed with no connection to the maternal tissues. According to these authors, the physical isolation of somatic embryos, demonstrated by their interdependence with the parental tissues, shows unicellular formation, i.e., propagules originate from asymmetric divisions of a single meristem cell.

Similar results were obtained by Silva et al. (2014) in a study on histodifferentiation events involved in the acquisition and development of somatic embryogenesis of oil palm via mature zygotic embryos, or rather, the formation of somatic embryos had unicellular origin, demonstrated by the cultures' physical isolation. On the other hand, in the somatic embryogenesis of zygotic embryos of Euterpe oleracea, Scherwinski-Pereira et al. (2012) observed that the formation of somatic embryos occurred via multicellular origin. The formation of somatic embryos of Euterpe oleracea started with the proliferation of meristem cells from the cultures' peripheral region, followed by the protoderm's differentiation and invagination. At the end of the process, cells similar to suspensor connected the somatic embryos to tissues of the source explant.

In the somatic embryogenesis of $B$. gasipaes via zygotic embryos, Steinmacher et al. (2011) did not register a tissue similar to the suspensor connecting the somatic embryos to their maternal tissues. However, they reported somatic embryos with a broad basal area fused with the parent tissue and demonstrated that the formation of the propagules also occurred from a multicellular origin.

During this period of cultivation, whitish regions, with a slightly translucent aspect, consisting of clusters of rounded structures, appeared at the edge of the embryogenic callus (Fig. 6a). The anatomical sections at this cultivation phase revealed small cell clusters among the meristem cells of the periphery of the embryogenic calli, indicating the onset of somatic pro-embryos. In current analysis, the somatic proembryos were shown to be individualized by an apparent
Fig. 5 Morphological and anatomical aspects of oil palm calli with formation of somatic embryos after 180 days in somatic embryo differentiation culture medium. a External morphology; b-d anatomical sections. $P C$ primary callus, $S E$ somatic embryos, gm ground meristem, $p d$ protoderm. Bars $\mathbf{a}=2 \mathrm{~mm} ; \mathbf{b}=0.5 \mathrm{~mm}$; $\mathbf{c}=0.2 \mathrm{~mm} ; \mathbf{d}=0.05 \mathrm{~mm}$
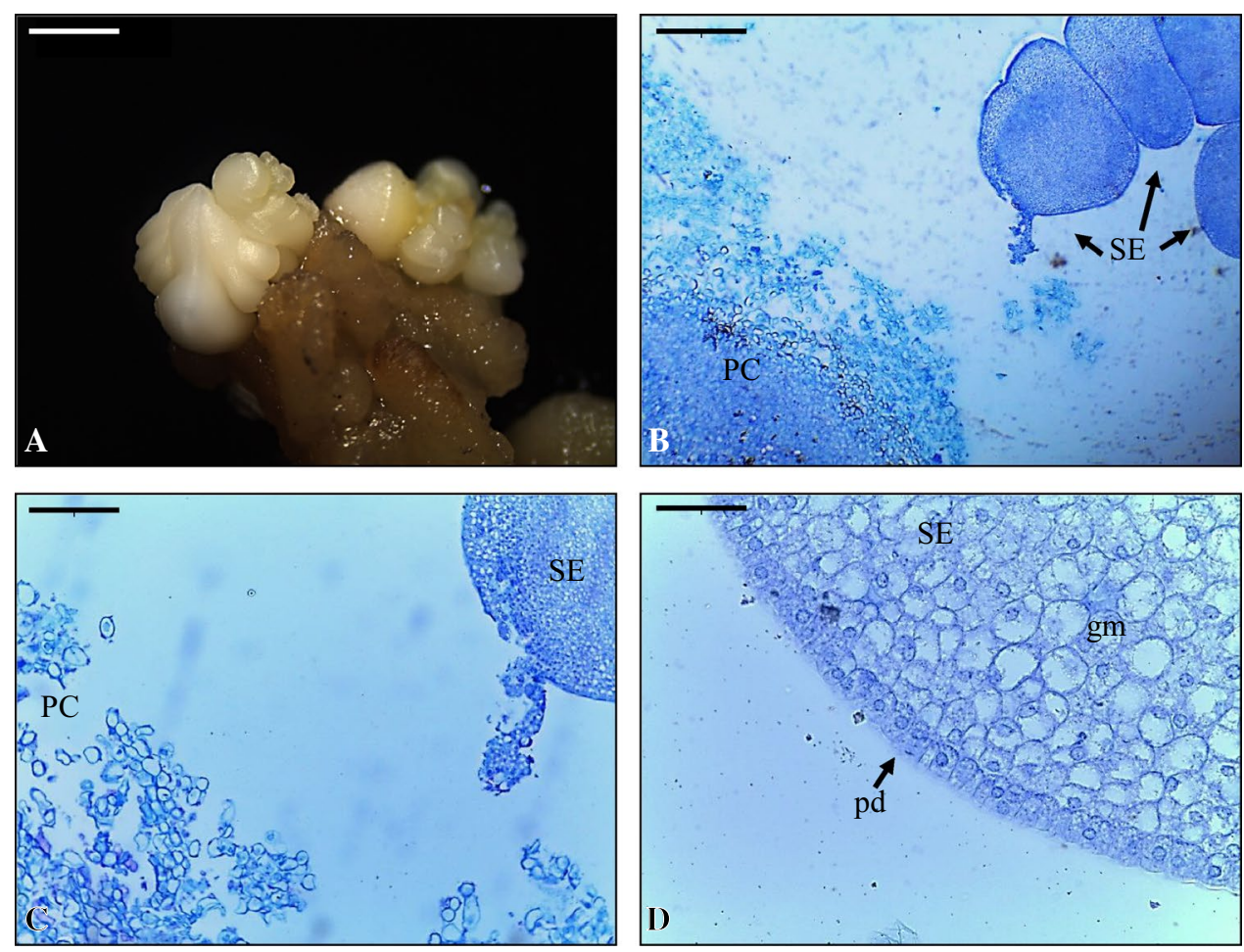
Fig. 6 Morphological and anatomical aspects of embryogenic calli with formation of pro-embryos after 90 days in somatic embryo differentiation culture medium and embryogenic calli with formation of somatic embryos after 180 days in somatic embryo differentiation culture medium. a, $\mathbf{e}$ External morphology; b-h anatomical sections. $E C$ primary callus, $P E$ pro-embryos, $E C$ embryogenic callus, $S E$ somatic embryos, $g m$ ground meristem, $p d$ protoderm. Bars $\mathbf{a}, \mathbf{e}=2 \mathrm{~mm}$; $\mathbf{f}=0.5 \mathrm{~mm} ; \mathbf{b}, \mathbf{g}=0.2 \mathrm{~mm} ; \mathbf{c}$, $\mathbf{d}=0.05 \mathrm{~mm} ; \mathbf{h}=0.05 \mathrm{~mm}$
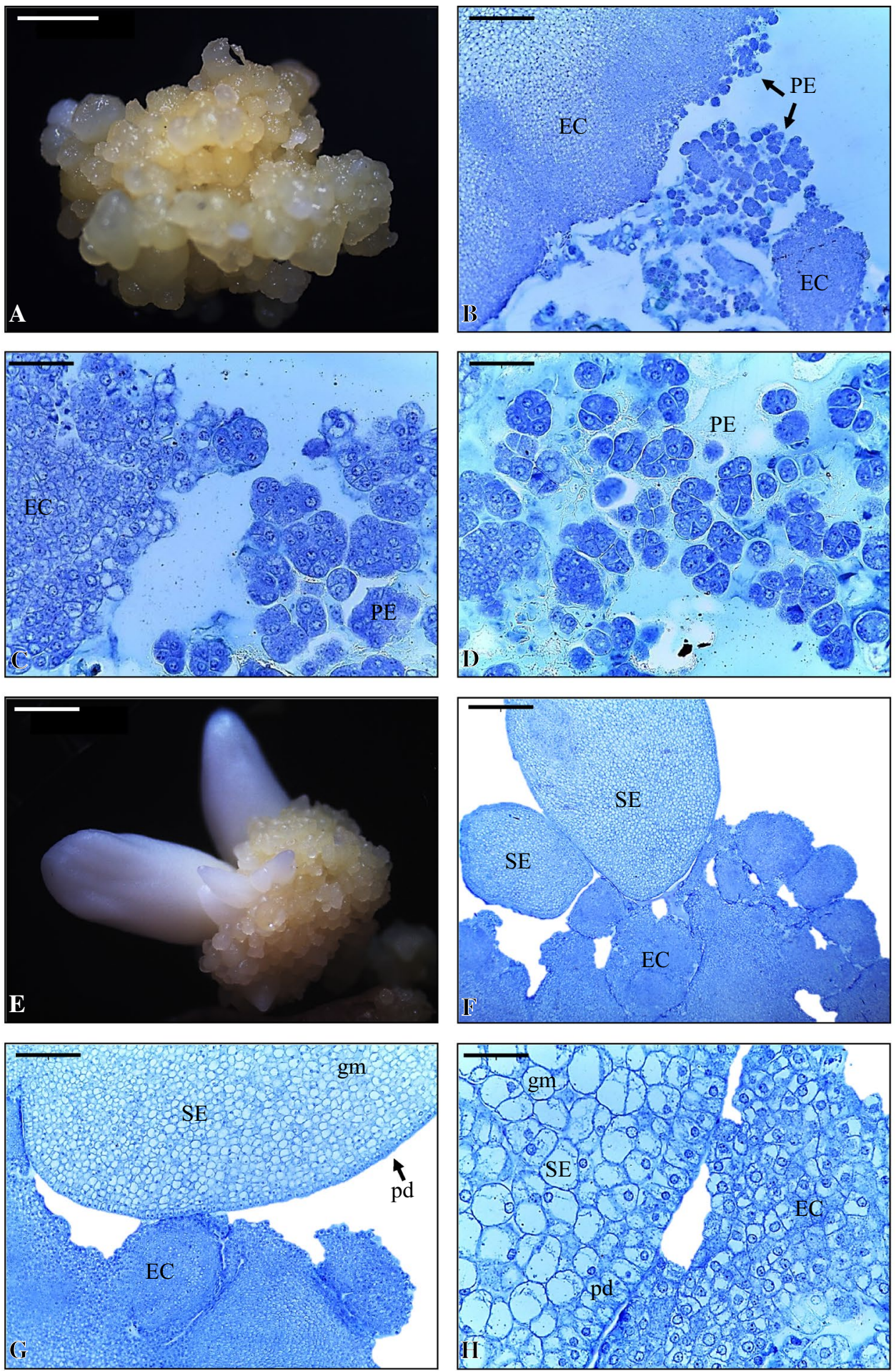

thickening of the cell wall, probably caused by the dissolution of the middle lamella (Fig. 6b-d).

These results have been corroborated by Thuzar et al. (2012) and Angelo et al. (2013) who, in their histological study of somatic embryogenesis of E. guineensis, also observed the formation of somatic pro-embryos from the physical isolation of meristematic cells derived from embryogenic masses in the differentiation process. In their study of morphological and anatomical aspects involved in the development of somatic embryogenesis of $P$. dactylifera, Davoodi et al. (2002) also registered that the formation of somatic pro-embryos occurred by the physical isolation of meristem cells present in the propagules during the differentiation process. 
According to Verdeil et al. (2001), the physical isolation of meristem cells in the formation of somatic pro-embryos may occur in different ways, such as by the thickening of the cell wall due to the dissolution of the middle lamella, by closing the plasmodesmata through callose deposition, by the accumulation of phenolic and lipophilic substances in the cell walls, and by the development of barrier cells that separate the somatic pro-embryos from the parental tissue. According to Moura et al. (2008), the physical isolation that somatic pro-embryos acquire during the course of the differentiation process provides meristem cells with the required isolation to promote their morphogenic reprogramming and to induce the onset of their embryogenic development.

As a result of this process, at the end of 180 days of culture in differentiation medium, the development of somatic pro-embryos into somatic embryos occurred in almost all the embryogenic calli cultivated. Somatic embryos originating from embryogenic calli were also morphologically characterized as exhibiting opaque aspect, whitish coloration and a slightly watery consistency. However, when somatic embryos originated from embryogenic calli, the latter frequently exhibited a slightly elongated shape (Fig. 6e). The histological sections at this stage of somatic embryogenesis of oil palm indicated the onset of differentiation of globular somatic embryos at an advanced stage of development, characterized by meristem cells completely bounded by a characteristic protoderm, albeit without procambium differentiation (Fig. 6f-h).
Results were similar to those reported by Balzon et al. (2013) who, in a study on the somatic embryogenesis of zygotic embryos of E. guineensis, also reported that the outer layer of meristem cells that constituted the somatic pro-embryos were differentiated in the protoderm, and thus provided for the formation of somatic embryos. In the anatomical analysis of callus formation and somatic embryogenesis of interspecific hybrids of Elaeis guineensis $\times E$. oleifera, carried out via mature fruit zygotic embryos, Angelo et al. (2013) also registered a significant formation of somatic embryos from the development of the meristem cells that comprised the somatic pro-embryos.

After 180 days of culture in differentiation medium, the somatic embryos were then transferred to an MS medium free of growth regulators to complete the maturation process and start regeneration. The somatic embryos inoculated at this stage of the process exhibited, in general, an opaque aspect, whitish coloration, a slightly watery consistency and a rounded to slightly elongated shape (Fig. 7a). The histological sections performed at this stage of development of the somatic embryos of oil palm (globular) revealed a well-defined protoderm, consisting of a uniseriate layer of strongly united rectangular-shaped cells with a clearly visible nucleus. The ground meristem, a region composed of a cluster of meristem cells, some having two nuclei and evidencing cell division, was surrounded by a layer of cells (Fig. 7b-d).

Through anatomical sections of globular embryos of A. aculeata originating from somatic embryogenesis of
Fig. 7 Morphological and anatomical aspects of somatic embryos in the globular stage after 180 days in somatic embryo differentiation culture medium. a External morphology; b-d anatomical sections. Arrow indicates cells in the process of cell division. $g m$ ground meristem, $p d$ protoderm. Bars $\mathbf{a}=2 \mathrm{~mm} ; \mathbf{b}=0.5 \mathrm{~mm} ; \mathbf{c}$, $\mathbf{d}=0.05 \mathrm{~mm}$
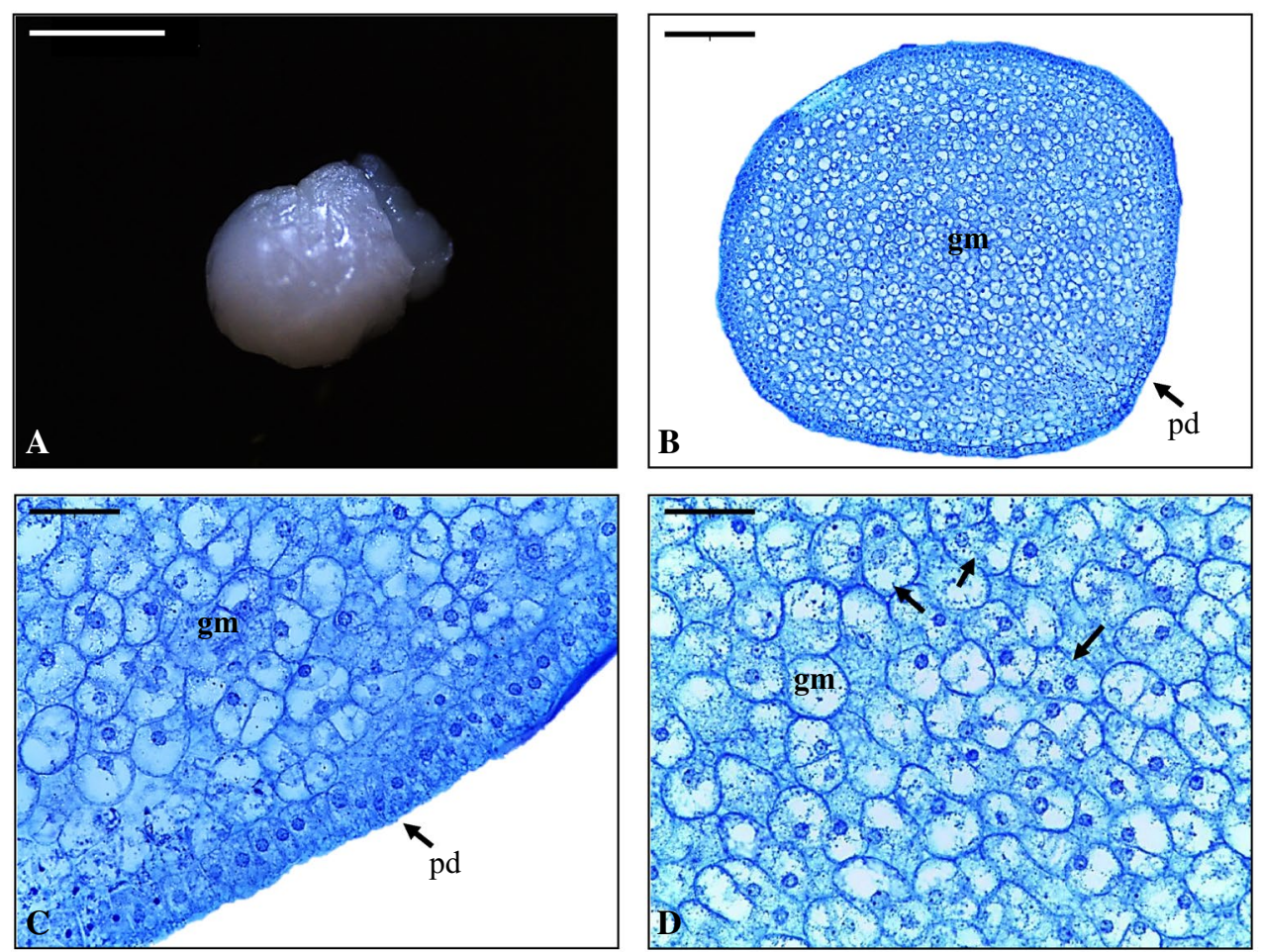
zygotic embryos, Moura et al. (2009) demonstrated a typical protoderm lining the mass of cells that composed the ground meristem, even without the development of procambial strands. Such results corroborated Steinmacher et al. (2007) in their study on the morphological and histological aspects of somatic embryogenesis of B. gasipaes via TCL technique, or rather, a characteristic protoderm delimiting the cells of the ground meristem occurred at this development phase of the somatic embryo. However, contrary to what has been observed in current analysis, procambial strands dispersed in ground meristem occurred in globular embryos of the species.

A significant quantity of torpedo-type somatic embryos was obtained after approximately 60 days of cultivation in an MS medium free of growth regulators. Somatic embryos at the torpedo stage, obtained at the end of somatic embryogenesis of immature leaves of oil palm, were morphologically characterized as exhibiting an opaque aspect, whitish coloration, slightly watery consistency and conical shape (Fig. 8a). The longitudinal sections performed during the maturation phase of the somatic embryo revealed a protoderm similar to that observed in globular somatic embryos, also composed of juxtaposed, rectangular-shaped external cells with prominent nuclei. The ground meristem was also reported enclosed by this casing structure, a region that, at this stage of development, was composed of layers of different-sized cells, larger at the center and smaller near the outskirts. Dispersed in the ground meristem, the onset of differentiation of the procambial strands was also observed. They formed narrow elongated cells with clearly visible nuclei (Fig. 8b-d).

In the histological analysis of somatic embryogenesis of $P$. dactylifera, Sané et al. (2006) reported a well-developed vascular system distributed throughout the meristem in longitudinal sections obtained from torpedo-stage somatic embryos. There were relatively well-organized apical regions at this development stage of the date palms' somatic embryo, unlike that observed in current study. Further, the stem's apical meristem was composed of a meristematic region surrounded by a leaf primordium, whilst the root's apical meristem was composed of slightly less organized diffuse area.

Further, the morphological and anatomical profile of torpedo-stage somatic embryos was compared to the profile of zygotic embryos extracted from ripe fruit to better understand the quality of somatic embryogenesis of oil palm from leaf explants. Morphologically, the mature fruit's zygotic embryos were characterized by an elongated shape, yellowish coloration at the apical section, whitish coloration at the basal part and a slightly translucent appearance (Fig. 8e). The longitudinal sections of mature zygotic embryos, as observed in somatic torpedo-stage embryos, also revealed a protoderm formed by external rectangular-shaped cells, juxtaposed, with prominent nuclei, delimiting the ground meristem, a region also consisting of several layers of cells with clearly visible nuclei and larger diameter, in which procambial strands, composed of narrow cells with an elongated shape and clearly visible nuclei could be observed (Fig. $8 \mathrm{f}-\mathrm{h}$ ).

Based on anatomical sections of zygotic embryos of $E$. guineensis extracted from mature fruits, Kanchanapoom and Domyoas (1999) stated that at this developmental stage, the zygotic embryos of oil palm are composed of three meristem tissues: the fundamental meristem, which is the precursor of parenchyma, collenchyma and sclerenchyma; the procambium, which is the precursor of vascular tissues (xylem and phloem); and the protoderm, which is the precursor of the epidermis. Results are similar to those reported by Silva et al. (2014), who also detected three different cell types in histological sections of mature fruit zygotic embryos of $E$. guineensis: fundamental meristem cells, procambium meristem cells and protoderm meristem cells. Results demonstrate major morphological and anatomical similarity that torpedo-stage somatic embryos, originating from somatic embryogenesis of immature leaves of oil palm, have with the species's mature fruit zygotic embryos.

In their anatomical and histochemical analysis of somatic and zygotic embryogenesis of A. aculeata, Moura et al. (2010) reported similarities between the torpedo-stage somatic embryos and mature zygotic embryos, although they detected a greater number of vacuolated cells, a lesser degree of differentiation of meristem tips and tissues, a shortage of amyloplasts, and the absence of proteins and lipids as reserve compounds. Sané et al. (2006) reported that in species of the Arecaceae family, somatic embryos generally differ from zygotic embryos merely by not exhibiting the accumulation of proteins and lipids as reserve compounds.

It has thus been demonstrated that the established protocol for micropropagation of oil palm did not result in the appearance of morphological and anatomical anomalies in the propagated cultures. Rather, several plants with normal growth and development were regenerated. The above results differ from those by Habib et al. (2012), who reported that large-scale somatic embryogenesis of E. guineensis was, in some cases, impaired by the regeneration of plantlets with abnormal development. However, most leaves in these plants were missing due to a partial necrosis of the leaf blades. There was still a process of atrophied growth in these specimens, also caused by several other histological and structural deficiencies (Habib et al. 2015). According to Moyo et al. (2015), mass micropropagation could still lead to the appearance of other undesirable morphological and anatomical features, such as deficiency in the production of pigments and waxes, 
Fig. 8 Morphological and anatomical aspects of a somatic embryo in torpedo stage after 60 days in MS medium free of growth regulators (a-d), and of a mature zygotic embryo (e-h). a-e External morphology; b-h longitudinal sections. $g m$ ground meristem, $p c$ procambium, $p d$ protoderm. Bars $\mathbf{a}-\mathbf{e}=2 \mathrm{~mm}, \mathbf{b}-\mathbf{f}=0.5 \mathrm{~mm}$; $\mathbf{c}-\mathbf{h}=0.05 \mathrm{~mm}$
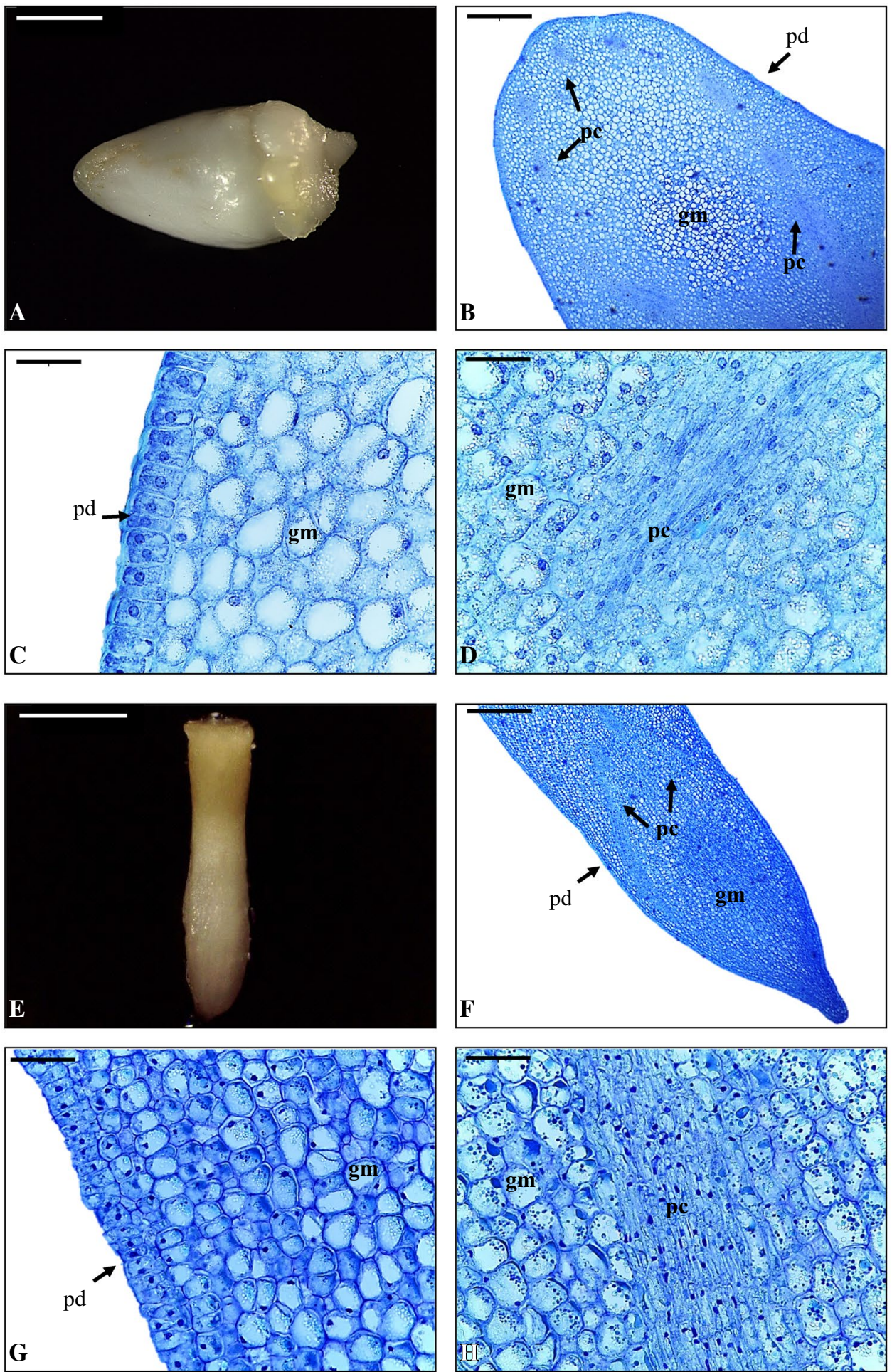

alterations in stomatal formation, water accumulation in the apoplast, reduction of the sustentation capacity and low vascularization.

During the somatic embryogenesis of the oil palm's immature leaves, the emergence of cell mass occurred after 60 days of cultivation by cell proliferation associated with vascular bundles of the initial explants. Based on this process, two different types of calli are formed, primary and embryogenic, consisting partially and totally of meristematic cell clusters, respectively. After 420 days of cultivation (including multiplication steps), these propagules form somatic embryos with no connection to the source 
tissues, initially composed (globular stage) of a very characteristic protoderm and ground meristem. When the cultures mature (torpedo stage) after 480 days of cultivation, procambial strands are also observed, a structural feature also seen in mature zygotic embryos. The above results provide an in-depth understanding of somatic embryogenesis of immature leaves of oil palm. They also demonstrate that the above methodology actually provides mature somatic embryos suitable for plant regeneration.

Further, current analysis develops morphological markers at different stages of development obtained during the process. It is thus possible to select more efficiently the immature leaves that will be used as initial explants, increasing the callus formation rates and reducing the damages caused in the matrices during the collection of tissues. Through such markers, calli with high embryogenic competence may be chosen more accurately in the establishment of suspension cell cultures, which may significantly increase the productivity of the somatic embryogenesis protocol. Finally, results may also be used to define the best period for the transfer of the materials to the subsequent stages for a more efficient process.

Acknowledgements The authors thank the Conselho Nacional de Desenvolvimento Científico e Tecnológico (CNPq Grant 426637/2016-0), Financiadora de Estudos e Projetos (Finep Grant 01.08.0597.01), and Coordenação de Aperfeiçoamento de Pessoal de Nível Superior (Capes/Embrapa 001-2011/Grant 39) for financial support and fellowships. We wish to thank Dr. Ricardo Lopes and Dr. Raimundo Nonato Vieira da Cunha (Embrapa Western Amazonia, Manaus, AM, Brazil) for providing the biological material for the experiments.

\section{References}

Alkhateeb AA (2008) A review the problems facing the use of tissue culture technique in date palm (Phoenix dactylifera L.). Sci J King Faisal Univ Basic Appl Sci 9:85-104

Angelo PCS, Steinmacher DA, Lopes R, Da Cunha RNV, Guerra MP (2013) Histological analysis and transcription profiles on somatic embryogenesis in interspecific hybrids of Elaeis guineensis $\times E$. oleifera. Agric Sci 4:1-11

Balzon TA, Luiz ZG, Scherwinski-Pereira JE (2013) New approaches to improve the efficiency of somatic embryogenesis in oil palm (Elaeis guineensis Jacq.) from mature zygotic embryos. In Vitro Cell Dev Biol-Plant 49:41-50

Besse I, Verdeil JL, Duval Y, Sotta B, Maldiney R, Miginiac E (1992) Oil palm (Elaeis guineensis Jacq.) clonal fidelity: endogenous cytokinins and indoleacetic acid in embryogenic callus cultures. J Exp Bot 43:983-989

Choi DS, Andrade MHC, Willis LB, Cho CW, Schoenheit J, Boccazzi P, Sambanthanmurthi R, Sinskey AJ, Rha CK (2008) Effect of agitation and aeration of yield optimization of oil palm suspension culture. J Palm Oil Res 1:23-34

Constantin M, Nchu WA, Godswill NN, Wiendi NMA, Wachjar A, Frank NEG (2015) Induction of oil palm (Elaeis guineensis Jacq. var. Tenera) callogenesis and somatic embryogenesis from young leaf explants. J Appl Biol Biotechnol 3:4-10
Corley RVH, Barret JN, Jones LH (1977) Vegetative propagation of oil palm via tissue culture. Oil Palm News 22:2-7

Davoodi D, Majidi E, Khoshkam S (2002) Some morphological and anatomical aspects of date palm (Phoenix dactylifera L.) somatic embryogenesis in tissue culture. J Agric Sci Technol 4:63-71

De Touchet B, Duval Y, Pannetier C (1991) Plant regeneration from embryogenic suspension cultures of oil palm (Elaeis guineensis Jacq.). Plant Cell Rep 10:529-532

Duval Y, Durand-Gasselin T, Konan KC (1988) In vitro vegetative propagation of oil palm (Elaeis guineensis Jacq.). Oleagineux 43:145-147

Duval Y, Engelmann F, Durand-Gasselin T (1995) Somatic embryogenesis in oil palm (Elaeis guineensis Jacq). In: Bajaj YPS (eds) Biotechnology in agriculture and forestry: somatic embryogenesis and synthetic seed. Springer, Berlin, pp 335-352

Gomes HT, Bartos PMC, Scherwinski-Pereira JE (2015) Optimizing rooting and survival of oil palm (Elaeis guineensis) plantlets derived from somatic embryos. In Vitro Cell Dev Biol-Plant 51:111-117

Gomes HT, Bartos PMC, Balzon TA, Scherwinski-Pereira JE (2016) Regeneration of somatic embryos of oil palm (Elaeis guineensis) using temporary immersion bioreactors. Ind Crops Prod 89:244-249

Habib SH, Syed-Alwee SSR, Ho CL, Ong-Abdullah M, Sinniah UR, Namasivayam P (2012) Morpho-histological characterization of truncated leaf syndrome seedlings: an oil palm (E. guineensis Jacq.) somaclonal variant. Acta Physiol Plant 34:17-28

Habib SH, Ho CL, Syed-Alwee SSR, Namasivayam P (2015) Molecular analysis on the shoot apical meristem of truncated leaf syndrome plantlets of oil palm (E. guineensis Jacq.). Plant Cell Tissue Org Cult 120:1023-1036

Hoffmann MP, Castaneda Vera A, van Wijk MT, Giller KE, Oberthür T, Donough C, Whitbread AM (2014) Simulating potential growth and yield of oil palm (Elaeis guineensis) with PALMSIM: model description, evaluation and application. Agric Syst 131:1-10

Jayanthi M, Susanthi B, Mohan NM, Mandal PK (2015) In vitro somatic embryogenesis and plantlet regeneration from immature male inflorescence of adult dura and tenera palms of Elaeis guineensis (Jacq.). SpringerPlus 4:256-262

Jones LH (1983) The oil palm and its clonal propagation by tissue culture. Biologist 30:181-188

Jouannic S, Lartaud M, Hervé J, Collin M, Orieux Y, Verdeil JL, Tregear JW (2011) The shoot apical meristem of oil palm (Elaeis guineensis; Arecaceae): developmental progression and dynamics. Ann Bot 108:1477-1487

Kanchanapoom K, Domyoas P (1999) The origin and development of embryoids in oil palm (Elaeis guineensis Jacq) embryo culture. Sci Asia 25:195-202

Konan KE, Durant-Gasselin T, Kouadio YJ, Flori A, Rival A, Duval Y, Pannetier C (2010) In vitro conservation of oil palm somatic embryo for 20 year on a hormone-free culture medium: characteristics of the embryogenic cultures, derived plantlets and adult palms. Plant Cell Rep 29:1-13

Leljak-Levanić D, Mihaljević S, Bauer N (2015) Somatic and zygotic embryos share common developmental features at the onset of plant embryogenesis. Acta Physiol Plant 37:127

Lim SL, Subramaniam S, Zamzuri I, Amir HG (2016) Biotization of in vitro calli and embryogenic calli of oil palm (Elaeis guineensis Jacq.) with diazotrophic bacteria Herbaspirillum seropedicae (Z78). Plant Cell Tissue Org Cult 127:251-262

Luis ZG, Scherwinski-Pereira JE (2014) An improved protocol for somatic embryogenesis and plant regeneration in macaw palm (Acrocomia aculeata) from mature zygotic embryos. Plant Cell Tissue Org Cult 118:485-496 
Luis ZG, Bezerra KMG, Scherwinski-Pereira JE (2010) Adaptability and leaf anatomical features in oil palm seedlings produced by embryo rescue and pre-germinated seeds. Braz J Plant Physiol 22:209-215

Moura EF, Ventrella MC, Motoike SY, De Sá Júnior AQ, Carvalho M, Manfio CE (2008) Histological study of somatic embryogenesis induction on zygotic embryos of macaw palm (Acrocomia aculeate (Jacq.) Lodd. ex Martius). Plant Cell Tissue Org Cult 95:175-184

Moura EF, Motoike SY, Ventrella MC, De Sá Júnior AQ, Carvalho M (2009) Somatic embryogenesis in macaw palm (Acrocomia aculeata) from zygotic embryos. Sci Hortic 119:447-454

Moura EF, Ventrella MC, Motoike SY (2010) Anatomy, histochemistry and ultrastructure of seed and somatic embryo of Acrocomia aculeata (Arecaceae). Sci Agric 67:399-407

Moyo M, Aremu AO, Van Staden J (2015) Insights into the multifaceted application of microscopic techniques in plant tissue culture systems. Planta 242:773-790

Murashige T, Skoog FA (1962) A revised medium for rapid growth and bioassays with tobacco tissue cultures. Physiol Plant 15:473-497

O’brien TP, Feder N, Mccully ME (1965) Polychromatic staining of plant cell walls by toluidine blue O. Protoplasma 59:368-373

Padua MS, Paiva L, Labory CRG, Alves E, Stein VC (2013) Induction and characterization of oil palm (Elaeis guineensis Jacq.) pro-embryogenic masses. An Acad Bras Cienc 85:1545-1556

Reinert J (1958) Morphogenese und ihre kontrolle an geweberkulturen aus karotten. Naturwissenschsften 45:344-345

Rival A, Aberlenc F, Morcillo F, Tregear J, Verdeil JL, Duval Y (1997) Scaling-up in vitro clonal propagation through somatic embryogenesis: the case of oil palm (Elaeis guineensis Jacq.). Plant Cell Tissue Cult Biotechnol 3:74-82

Sané D, Aberlenc-Bertossi F, Gassama-Dia YK, Sagna M, Trouslot MF, Duval Y, Borgel A (2006) Histocytological analysis of callogenesis and somatic embryogenesis from cell suspensions of date palm (Phoenix dactylifera). Ann Bot 98:301-308

Scherwinski-Pereira JE, Guedes RS, Silva TL, Fermino Junior PCP, Costa FHS (2010) Somatic embryogenesis and plant regeneration from oil palm thin cell layer. In Vitro Cell Dev Biol-Plant 46:378-385

Scherwinski-Pereira JE, Guedes RS, Silva RA, Fermino Junior PCF, Luis ZG, Freitas EO (2012) Somatic embryogenesis and plant regeneration in açaí palm (Euterpe oleracea). Plant Cell Tissue Org Cult 109:501-508

Schwendiman J, Pannetier C, Michaux-Ferriere N (1988) Histology of somatic embryogenesis from leaf explants of the oil palm Elaeis guineensis. Ann Bot 62:43-52
Silva RC, Luis ZG, Scherwinski-Pereira JE (2012) Differential responses to somatic embryogenesis of different genotypes of Brazilian oil palm (Elaeis guineensis Jacq.). Plant Cell Tissue Org Cult 111:59-67

Silva RC, Luis ZG, Scherwinski-Pereira JE (2014) The histodifferentiation events involved during the acquisition and development of somatic embryogenesis in oil palm (Elaeis guineensis Jacq.). Plant Growth Regul 72:67-80

Soh AC, Wong G, Tang CC, Chew PS, Chong SP, Ho YW, Wong CK, Cho CN, Nor Azura H, Kumar H (2011) Commercial-scale propagation and planting of elite oil palm clones: research and development towards realization. J Oil Palm Res 23:935-952

Staritsky G (1970) Tissue culture of the oil palm (Elaeis guineensis Jacq.) as a tool for its vegetative propagation. Euphytica 19:288-292

Steinmacher DA, Krohn NG, Dantas ACM, Stefenon VM, Clement CR, Guerra MP (2007) Somatic embryogenesis in peach palm using the thin cell layer technique: induction, morpho-histological aspects and AFLP analysis of somaclonal variation. Ann Bot 100:1-11

Steinmacher DA, Guerra MP, Saare-Surminski K, Lieberei R (2011) A temporary immersion system improves in vitro regeneration of Peach palm through secondary somatic embryogenesis. Ann Bot 108:1463-1475

Teixeira JB, Sondahll MR, Kirby EG (1994) Somatic embryogenesis from immature inflorescences of oil palm. Plant Cell Rep $13: 247-250$

Thuzar M, Vanavichit A, Tragoonrung S, Jantasuriyarat C (2012) Recloning of regenerated plantlets from elite oil palm (Elaeis guineensis Jacq.) cv. Tenera. Afr J Biotechnol 11:14761-14770

Verdeil JP, Hocher V, Huet C, Grosdemange F, Escoute J, Ferriere N, Nicole M (2001) Ultrastructural changes in coconut calli associated with the acquisition of embryogenic competence. Ann Bot 88:9-18

Wahid MB, Abdullah SNA, Henson IE (2005) Oil palm-achievements and potential. Plant Prod Sci 8:288-297

Wiendi NMA, Constantin M, Wachyar A (2015) Study of oil palm (Elaeis guineensis Jacq) in vitro embryogenesis using young leaves explants. J Trop Crop Sci 2:5-9

Williams EG, Maheswaran G (1986) Somatic embryogenesis: factors influencing coordinated behaviour of cells as an embryogenic group. Ann Bot 57:443-462 